\title{
The Arcadian Federation: A Benchmark for the Further EU Integration
}

\author{
Emmanouil M. L. Economou (Corresponding author) \\ Department of Economics, University of Thessaly \\ PC 38446, Korai 43 Street, Volos, Greece \\ E-mail: emmoikon@uth.gr \\ Nicholas K. Kyriazis \\ Department of Economics, University of Thessaly \\ Nevada State University \\ PC 38446, Korai 43 Street, Volos, Greece \\ E-mail: nkyr@uth.gr
}

Received: May 25, 2014 Accepted: June 22, 2015 Published: June 23, 2015

doi:10.5296/jsss.v2i2.7673 URL: http://dx.doi.org/10.5296/jsss.v2i2.7673

\begin{abstract}
In the present paper we analyse the institutional set-up of the Arcadian federation, a Greek democratic federation, through an interactive analysis. We compare its federal political and economic institutions with the European Union (EU) in order to show if the ancient federation can offer us any institutional feedback for the further integration of the EU. We present its institutional (political and economic) set ups and then discusses differences and similarities. We have found that some of the basic Arcadian federal institutions could serve as a benchmark for the further promotion of democratic procedures and social cohesion in the EU.
\end{abstract}

Keywords: Federations, Democratization, Cohesion, Arcadian Federation, EU 


\section{Introduction}

The issue of federalism is an important aspect of our modern societies. A federal state is considered to be one that is characterized by a union of partially self-governing states or regions under a central (federal) government. Under a federal state, each member-state retains control of its own internal affairs, but it willingly decides to accept collaboration and to give certain powers to a central government, while keeping control over local matters.

Thus, a federation often emerges when states wish to deal with mutual problems, such as defense. So far, there are many federal states worldwide. Figure 1 displays a representation of federal states (in green) in comparison to unitary states (in blue). It can be seen that some of the largest states in the world, in terms of population size, such as India, (the most populous democratic federation in the world, with a population of 1.28 billion people), Pakistan and the USA, or in terms of geographical size, such as the Russian federation or Canada, are federations.

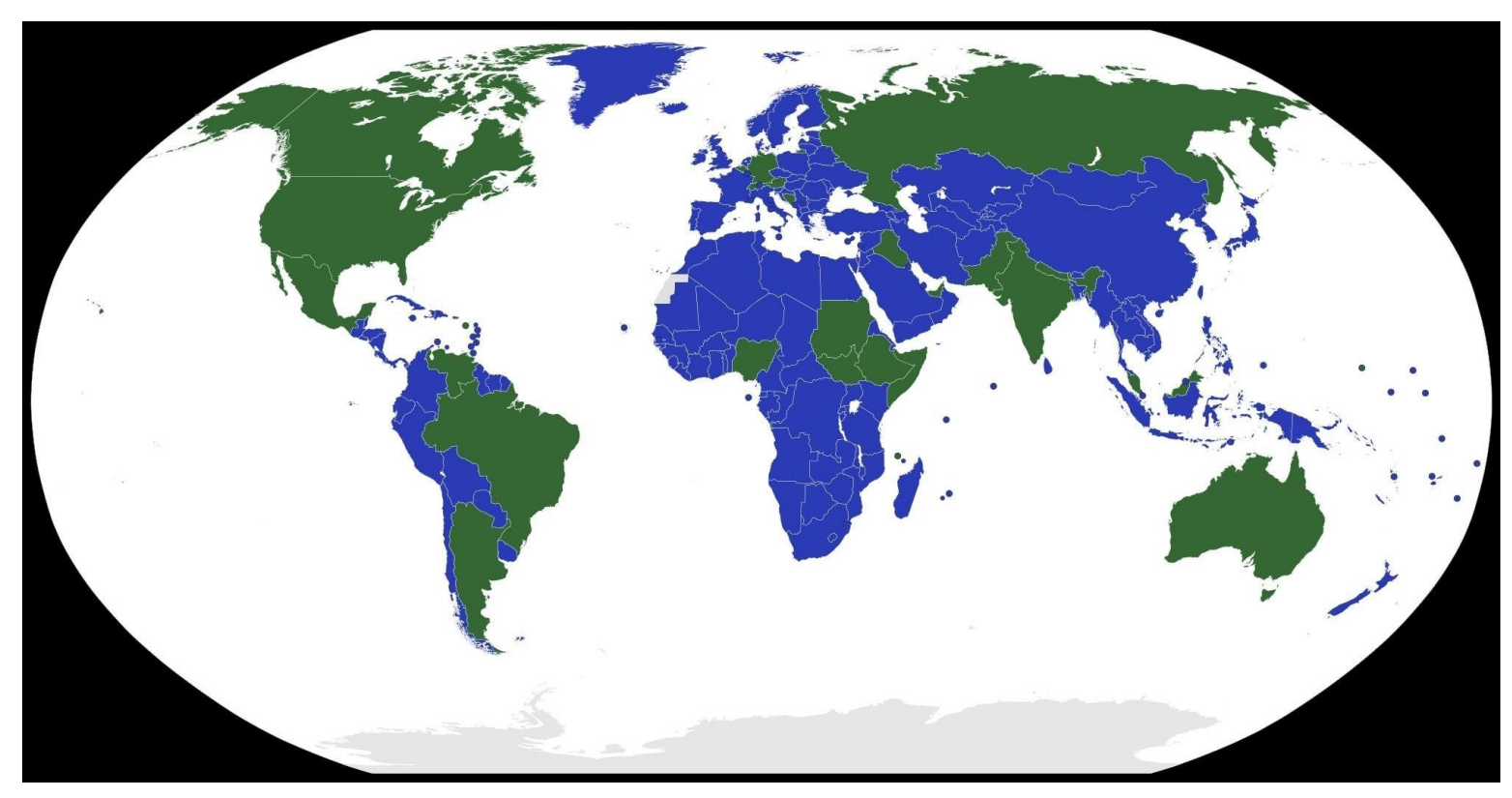

Figure 1. Federal states worldwide

http://en.wikipedia.org/wiki/Federation\#/media/File:Map_of_unitary_and_federal_states.svg

In Europe there are many federal democratic federations, such as Switzerland, which implement many direct democracy procedures, such as referendums and initiatives (Note 1) (Kaufmann, 2004; et. al, 2010). Switzerland is not a member of the EU. Other European Union states such as Belgium and Germany consist of federal entities, which are also members of the EU. For example, Germany is comprised of 16 federal states called Bundesländer. Neighboring Austria and its Bundesländer was a unitary state with administrative divisions that became federated. 
Thus, the issue of federations is rather important. According to Weingast (1997) citizens wish "to defend the system" (meaning the political system) when they are satisfied by its functioning by taking into account the opportunities it offers them. Based on this view we think that if a federal structure functions properly, citizens have many reasons to wish to participate in these federal structures.

However, it appears that the situation is not as good as it should be. Citizens globally are gradually becoming frustrated by the functioning of our modern democracies. In Europe, for example, there is great dissatisfaction regarding the workings of democracy. This, unfortunately, is obvious. Euroscepticism is growing in all $28 \mathrm{EU}$ member-states. In France, Great Britain, Greece, Italy, Hungary, etc., anti-European parties are steadily increasing their positions by adding new voters to their force. Why is this happening?

An increasing number of European citizens believe that there is a serious democratic deficit and thus legitimation of the EU institutional bodies, and lack of solidarity and cohesion. This has resulted in a growing Euroscepticism (Note 2). In this paper, by analyzing the federal institutions of the Arcadian federation, we will attempt to offer some institutional proposals for making the EU more stable and more legitimate in the eyes of its citizens. However, we think that it is necessary to admit at this point that such an analysis needs careful handling since we are referring to a historical case study which dates back in time, thus any argumentation or proposal must be conducted cautiously. This is mainly because we lack sufficient historical data as well as secondary analysis and any statistical evidence (Note 3). On the other hand, such an analysis is innovative in nature and offers a further contribution to the literature of both ancient economies, the theory of federalism and EU politics.

Our paper is organized as follows: In Section 2 we offer a brief historical background of the Arcadian federation, while in Sections 3 and 4 we analyse in brief the Arcadian federation's political and economic institutions. Then in Section 5 we compare these institutions under a very specific set of criteria with a modern case, the EU, and finally, we conclude with our own suggestions and proposals for modern policymakers. So far, we have analysed ancient Greek federal states such as the Aetolian and the Achaean federations by focusing on their institutions concerning how some elements could be adaptable and useful for our modern societies (see Economou \& Kyriazis, 2013; Economou, Kyriazis, \& Metaxas, 2014). But it is the first time, as far as we know, that the case of the Arcadian federation is analysed under such a perspective.

Thus, we hope to contribute to the international literature by covering this issue in two ways: On the one hand to analyse what has up to now been a neglected federal entity, the Arcadian federation, and on the other hand, to find the link between ancient and modern federal institutions.

\section{The Arcadian Federation: A Brief Historical Context}

Many scholars such as Freeman (1893, 2013), Mitsos (1947), Badian (1952), Larsen (1971, 1972, 1975), Davis (1978), Mackil (2013), Economou and Kyriazis (2013), Economou, 
Kyriazis and Metaxas (2014) have already analysed ancient Greek federal states by focusing primarily on the Achaean, Aetolian and Boeotian cases.

In this paper, we focus on the Arcadian case. The reason that this interesting case is not very well known is because of its relatively short period of existence (370-230 BCE). Thus, we lack sufficient historical data to analyse it in more detail, as for example with the case of the Aetolian federation (420-168 BCE) which had a longer historical span.

The Arcadian League was formed in 370 BCE. It was the result of the geopolitical gap that emerged after the defeat of the Spartan army by Theban troops in the Battle of Leuktra in 371 BCE. A conflict between Tegea and Mantineia, two of the largest neighboring democratic cities-states of Arcadia, in terms of population, was emerging. The main concern for the Arcadians was whether the Arcadian cities should take the side of the winners, the Thebans of the Boeotian League, or if they should remain under the geopolitical influence of the defeated Spartans and their allies at that time, the Athenians. Mantinea chose to side with Sparta and Athens, while Tegea and Megalopolis remained loyal to Thebes.

Finally, this tension led to the creation of a federal structure in order to solve the dispute in a way that gave greater weight to the common good than to local city-state affairs and interest groups. In order for the competition between the two cities to be solved efficiently, it was decided by the policymakers of both cities that a new capital city must be created. The new city was called Megalopolis (Paus. Hell. Per. 8.27; Diod Sic. Hist. Libr. 15.94). The federal perspective, which included a closer relationship and collaboration with Tegea was seen favourably in Mantineia, whereas in Tegea it led to civil strife. Finally, the Tegeans accepted to become part of the federation, after taking into account also the contradicting wishes of the Boeotian federation and their antagonists, the Alliance of Sparta and Athens (Sakellariou, 1972; Cartledge, 1987; Mosse, 2000).

However, in 362 BCE the federation's unity was in great jeopardy as the Boeotian federation, and their strongest member, Thebes, wanted to dissolve it. Mantinea sided with Sparta and Athens, while Tegea and Megalopolis remained loyal to Thebes. This led to the Battle of Mantinea that year which, however, did not lead to the dissolution of the Arcadian federal state but rather, as it seems, to the limitation of its influence. The federation was in existence during the $3^{\text {rd }}$ century BCE. Its final dissolution took place sometime during the $230 \mathrm{~s}$, as the Arcadian cities joined the neighbouring Achaean federation (Roy, 2005).

\section{The Political Organization of the Arcadian Federation}

The Arcadian federation comprised two main institutional bodies. The first was the federal pan-Arcadian Assembly, in which all citizens of all constituting city-states aged 30 and over could participate. The Assembly was in session for three days, and although the ancient sources do not clarify if the assembly took place once or twice a year, in all probability, it took place twice a year as this was the common practice with other Greek democratic federations of that time, the Achaean, the Boeotian and the Aetolian federations (Economou and Kyriazis, 2013; Mackil, 2013; Economou, Kyriazis, \& Metaxas, 2014). In the Arcadian federal assembly, all citizens from each city-state member of the federation could participate. 
There, they could vote for a series of major political issues, such as war or peace, economic policy, taxation etc.

The pan-Arcadian citizen assembly was responsible for the election of the governing body for the following year. This assembly was called The Myrioi, meaning "the many", or "a very large number" (of citizens). Ancient and modern sources argue that the Myrioi were actually a body of 10.000 citizens (Xen. Hell 6.5.5, 7.1.38, Diod Sic. Hell 15.59, Paus. Hell. Per. 8.32.1; Sakellariou, 1972; Roy, 2000) which means that in order for the federal assembly to take place, it required a quorum of 10.000 citizens. For example, as we know from the case of ancient Athens, the famous Athenian assembly of citizens required a quorum of 6.000 (Hansen, 1999). Trampedach (1994) verifies our conjecture to this point. He argues that the requirement for 10.000 citizens is actually a minimum margin, since it is logical to believe that some citizens from city-states that were not located close to Arcadia's capital, Megalopolis, probably found it more difficult to participate than those citizens who came, for example, from states that were close to Megalopolis.

This also means to us, that citizens of the neighboring states tended to be overrepresented in the federal assembly, as opposed to citizens of states that were located further away. In conclusion, Tsiolis (1995) argued that the quorum required was actually a minimum of 6.000 citizens, as was the case with the Athenian democracy. The assembly's venue had a capacity of 6.000 seats. If more participants attended, the venue was capable of hosting up to 10.000 . However, what is the most important aspect to mention at this point is the fact that citizens from all city-states had the opportunity to participate in the procedures of the assembly twice a year. The Assembly meeting was actually a "referendum" if we interpret it in modern terms. And in our modern societies, we don't know yet of many cases far from the direct democratic procedures in the modern Swiss cantons, or in the German Bundesländer of Bavaria, or some states in the USA such as California and in Uruguay and New Zealand, that direct procedures really take place to such an extent, as with the case we describe here. (Kaufmann et al. 2010, p. 223) (Note 5).

The second pivotal political body was the Council of the "50 Damiourgoi". It was actually a council probably intended for handling administrative matters and a preliminary body which introduced the main issues of discussion during the Assembly's gatherings, having as a model the Council of the 500 members of Athens. The members of the Council were locally elected in their home city-states, like the members of modern national parliaments. Each city-state had the right to send 50 elected representatives to prepare the agenda of discussion for the assembly (Sakellariou, 1972; Roy, 2000). Ancient sources are not accurate on this point and this has led to different interpretations. For example, Mosse (2000, p. 2003) argues that each city could provide 20 instead of 50 representatives to the Council. However, according to our view, the more crucial element, far from the discussion concerning the number of the representatives, is that with the Greek federal entities, a mixed democratic system where direct democratic procedures (the Assembly of citizens) and indirect (representative) procedures (the Council) was actually in existence. As far as we know, this was an institutional innovation that appeared for the first time in antiquity with the ancient Greek federations. 
The Arcadian federation had a government body that was directly elected democratically by the federal Assembly of citizens. In all probability this body comprised 10 members, as was the case with the Achaean federation. The highest in hierarchy among them was the Strategos, literally meaning the General, who combined both the office of the political head of the federation and the supreme military commander of the armed forces somewhat like the de facto position of George Washington during 1776-1783, or Napoleon Bonaparte during 1798-1814. The fact that the Strategos was elected by his compatriots is important, since for example, the President of today's EU is not elected by the European citizens, but in contrast, he/she is appointed, thus, it has only an indirect legitimacy in the eyes of European citizens.

Far from the fact of the proper mixture of both direct and indirect democracy procedures, another key institution of the federation was single citizenship (in Greek, "isopoliteia") of its constituents. Single citizenship meant that a citizen could have political, civil and property rights in any city-state throughout the Arcadian dominion (Schwahn, 1931b; Mackil, 2013, pp. $255,263,266)$, a situation that clearly goes beyond today's European Union. Transferring this process to modern EU, it could mean for example, that Dutch people could go and live in Portugal, where automatically they could have voting rights in Portuguese national elections and also enjoy property and civic rights there and vice versa.

Another institutional innovation was the introduction of federal judicial procedures. Federal courts were empowered to solve disputes not only between city-states when serious disputes arose, but also cases between individuals, including criminal and property rights cases (Ager, 1996). Furthermore, for security reasons, the federation maintained a standing federal army, called epilektoi. It was a body of 5.000 highly trained soldiers who received a salary for their services (Diod. Sic Hell. 15.67.2). This organization was similar in nature to modern armies who use salaried personnel. There was also another body called eparitoi, comprised citizen-soldier militia who were also paid by the federal budget for their services (Xen. Hell. 7. 4. 33-4; Fine, 1983, p. 595; Roy, 2000). The federation could mobilise a ceiling of as high as 25.000 men in extreme situations (Sakellariou, 1972). Such a high concentration of troops at that time means that the Arcadians could shape a very strong and formidable army if they wished to do so.

\section{The Economic Organization of the Arcadian Federation}

The Arcadian federation was a multicurrency area. Like the majority of the Greek federal entities of the time, there was a parallel circulation of both federal and city-state coins (Lewis, 1997; Mackil 2013). However, we don't know what the analogy of federal to city-state coins was or under which procedures these coins were minted.

The reasons for keeping parallel currencies of the same value must have been twofold, both economic and political. For economic reasons, each city-state would gain some revenue out of the issuing of coins in the form of seignorage (Note 6). Politically, it would be a kind of prestige and display of some degree of independence, perhaps in keeping with the tradition of having their own separate coinage. 


\section{Macrothink}

We don't have any evidence for the composition of the federal budget. However, based on some modern interpretations of Scholten (2000), Mackil (2013), Economou, Kyriazis and Metaxas (2014) we argue that state revenues must have come from city-state contributions through taxation, custom duties levied on exports and imports, grants by wealthy citizens in order to increase their personal reputation and political prestige, liturgies, a very special type of taxation levied on the wealthy citizens (see Gabrielsen, 1994; Lyttkens, 1994; Kyriazis, 2009), loans to the state offered by private investors and possibly and military plundering, a habitual action during periods of war after successful war campaigns (see de Laix, 1973, p. 60). Concerning federal budget expenses, unfortunately we do not have sufficient evidence for extracting specific results.
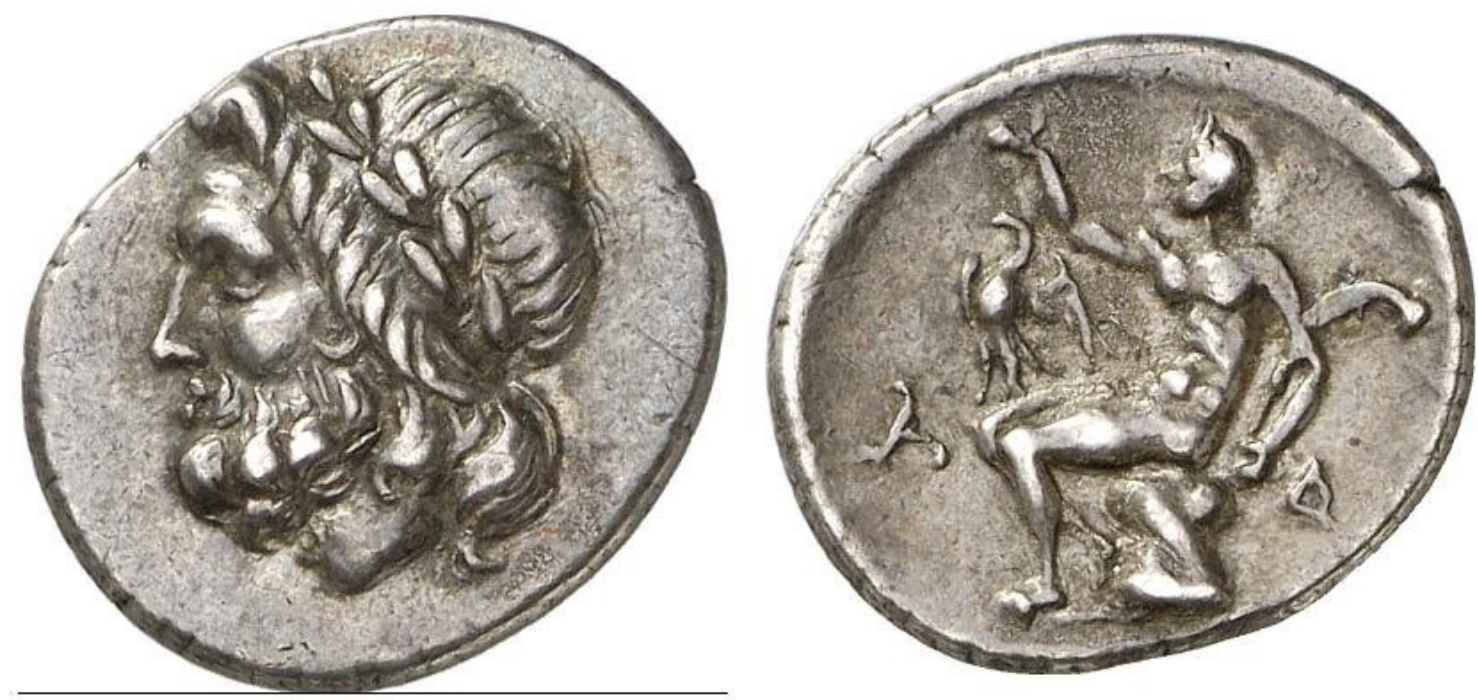

Figure 2. Federal Arcadian triobol. A sub-division of the drachma coin

Source: http://www.sixbid.com/browse.html?auction=142\&category=253\&lot=1329

In this section we have analysed the institutional framework of the Arcadian federation based on available ancient sources and modern literature and we have attempted to answer some related questions based on logical deductions, in cases where evidence was not adequate.

\section{The Institutional Set up of Federations: A Comparison}

The first column of Table 1 presents a series of criteria through which we compare the Arcadian federation with the EU through an interactive analysis. We compare our two cases through five very specific criteria: Democratic Structure, Common citizenship, Common Foreign and Security Policy, Federal Justice and Monetary union. We do not consider such an analysis as an anachronism since we compare the Arcadian federation and the EU under a very specific set of criteria which measure the level of the implementation of democratic procedures and the level of economic cohesion. 
Concerning the first criterion, direct democratic procedures were part of the Achaean federation's institutional organization. To start with, in Section 3 we have already referred to the two yearly gatherings of citizens, under which, any citizen from any city-state could participate and vote for a series of important issues such as war and peace, federal fiscal policies, etc. In these two assembly gatherings, 10 prominent and prestigious federal citizens were elected by their compatriots as the members of the government board for the following year. This is a crystal clear democratic procedure. Thus the head of the state, the Strategos and his colleagues, the 10-member government board, were elected representatives of the federal citizens, being approved by the citizens' federal assembly, through a direct democratic procedure: universal voting. In addition, the Arcadian Council's representatives, who set the agenda of discussion for the Assembly, were democratically elected in their city-states.

Table 1. Comparison between the institutional organization of the Arcadian federation and the EU

\begin{tabular}{|c|c|c|}
\hline Criteria & Arcadian federation & $\mathbf{E} \mathbf{U}$ \\
\hline $\begin{array}{l}\text { Democratic } \\
\text { Structure }\end{array}$ & $\begin{array}{l}\text { An efficient mixture of } \\
\text { both direct (the } \\
\text { Assembly and the } \\
\text { government) and } \\
\text { indirect democracy (the } \\
\text { Council) }\end{array}$ & $\begin{array}{l}\text { Elements of direct democracy in national and } \\
\text { regional level through referendums in some } \\
\text { member states }\end{array}$ \\
\hline $\begin{array}{l}\text { Common } \\
\text { citizenship }\end{array}$ & Yes, single citizenship & No common citizenship yet \\
\hline $\begin{array}{l}\text { Common } \\
\text { foreign and } \\
\text { external policy }\end{array}$ & $\begin{array}{l}\text { Federal armed forces } \\
\text { (army and navy) }\end{array}$ & $\begin{array}{l}\text { Not efficient yet } \\
\text { No common federal pan-European armed forces } \\
\text { yet }\end{array}$ \\
\hline Federal Justice & $\begin{array}{l}\text { Efficient level of justice } \\
\text { (Local and federal } \\
\text { courts in the federal } \\
\text { member city-states and } \\
\text { in the Capital }\end{array}$ & $\begin{array}{l}\text { Efficient level of justice } \\
\text { European Court of Justice } \\
\text { (Luxembourg) }\end{array}$ \\
\hline $\begin{array}{l}\text { Monetary } \\
\text { union }\end{array}$ & $\begin{array}{l}\text { Yes, parallel circulation } \\
\text { of both federal and local } \\
\text { coins in city-states }\end{array}$ & Common currency for the Eurozone members \\
\hline
\end{tabular}


By contrast, in today's EU, the post of President of the EU is not open to all citizens, since it is based on, according to negotiations, candidates proposed by the national governments. In fact, the only elected body in the EU is the European parliament, which has limited competencies (compared to those of national parliaments) although they have increased during the preceding years.

However, even the European Parliament (EP) is not a true legislative body, since European legislation is initiated by the European Commission, sent to the Council of Ministers and then finally to the EP. The members of the European Commission, the executive body that proposes legislation, implements decisions, safeguards the EU treaties of the European Union and manages the daily business of the EU, are also non-elected, which is another aspect of the EU's democratic deficit.

Concerning the second criterion, that of common citizenship ("isopoliteia"), we have already argued that common citizenship was practiced in real terms in the Arcadian federation. Thus, the federation practiced efficiently three of the main principles of economic freedom in the modern sense: free mobility of goods, labour and capital. By contrast, the EU does not practice common citizenship, at least not yet. This, according to our view, does not lead to transactional cost reduction since the movement of citizens and capital cannot be achieved as fast as it could. Thus, economic mobility and economic transactions achieve inferior results. Furthermore, EU citizens don't feel that they have a common origin and identity, as the Arcadians did, since they feel that they still don't have common opportunities, privileges and responsibilities.

Furthermore, the Greek federation should be regarded as superior to the EU as far as foreign policy and defence issues are concerned. Except for the first years of tension between Tegea and Mantineia, the Arcadian federation had a coherent policy which explains why the federation managed to continue to exist for one and a half centuries, in an era of harsh geopolitical competition and civil warfare in mainland Greece (Note 7). On the other hand, the EU, although it has already introduced the Eurocorps and the EU Battlegroups as military means in order to achieve an effective Common Foreign and Security Policy (CFSP), still needs to take further steps so as to be implemented in an efficient way. CFSP is not as functional as it should have been in practical terms. Europeans still don't share a coherent foreign and security policy.

A variety of different views and approaches by the member states for major security policy issues such as the two wars in Iraq, in 1991 and 2003, the war in Serbia in 1999 and the recent manipulation of Iran's nuclear potential or recent crisis indicates that there is not yet a coherent and efficient CFSP. However, it appears that the Europeans implemented a more coherent strategy as far as the political aspect of the recent crisis in Ukraine is concerned. Nevertheless, there is much inefficiency concerning the structure, logistics and functioning of the member-states' armed forces, the structure of the European defense industry and the level of interoperability between each state's armed forces troops. There are also major inefficiencies due to the large variety of different types of weapon systems that the EU armed forces use separately. For these reasons Hartley $(2003,2007)$ and Metaxas and Economou 
(2012), among others, prove that there is not an efficient level of a coherent CFSP as yet (Note 8).

Concerning federal justice, the Arcadian federation offered efficient federal judicial services to its citizens (Ager, 1996; Mackil, 2013). This happens efficiently in today's EU through its main institutional judicial institutions, the European Court of Human Rights in Strasbourg and the European Court of Justice in Luxembourg. Finally, concerning the last criterion, federal currency, the Arcadian federation utilized both parallel and local coins. However, what is important is the fact that all city-states shared a common federal Arcadian coin. The Arcadian federal coin was a mechanism for achieving faster economic transactions and showing the prestige of the federation. By contrast, in the EU, only 19 out of $28 \mathrm{EU}$ member-states share the euro which is under the aegis of the European Union Central Bank (ECB) (Note 9).

\section{Conclusions: The Working of Democracy}

With this paper we have analysed the Arcadian federation, an ancient Greek federal state, by comparing it with the modern EU, a would-be federation in order to see if the Greek federal state can offer any institutional ideas and proposals for the further integration of the EU. According to the Freedom House's Report for 2013, the quality of democratic procedures declined for the eighth consecutive year. Democratic procedures backed down in 54 countries, in comparison to 40 countries in which they have been developed (Note 10). To analyse how democratic federations are, we focused on five specific criteria, democratic structure, common citizenship, Common Foreign and Security Policy, federal justice and monetary union.

We have found that except in the case of federal justice and the monetary union, the EU lags behind the Arcadian federation in terms of direct democratic procedures and social cohesion. Thus, a series of proposals can be extracted by our analysis. First of all, if the EU policymakers really wish the EU to progress towards becoming a true federation, they should introduce more democratic procedures in the form of binding popular initiatives of citizens (direct democracy), more frequent referendums on the EU level for crucial issues, such as whether citizens are in favour of or against a common EU Constitution. Also, the institutional bodies of the EU must have a greater legitimacy in the eyes of the European citizens. To achieve this we propose that the President of the EU and the EU Commissioners should be elected by universal vote by all European citizens, instead of being elected. Their election could be achieved in practical terms through an institutionalised pan-European referendum.

Linked to this, to increase cohesion, the EU has to increase its federal budget intended for redistribution of money so as to implement social policies such as economic relief to special social groups and to establish a higher European budget for regional and social policies as a whole. In other words, the EU should launch anti-austerity and development projects throughout the EU.

Furthermore, single citizenship, which is an important element of promoting regional economic mobility, commerce and political cohesion, should be adopted on the EU level in order to promote further a common European identity and social cohesion. However we must 
acknowledge that achieving single citizenship as a means of promoting a common pan-European common identity is not a simple and easy procedure. Our two case studies differ in some basic socio-economic elements. Firstly, Arcadian citizens shared a common national identity thus achieving cohesion and single citizenship was easier compared to today's EU member states, where there are 28 different (or relatively different in some cases) national identities. Thus, social and national diversities make cohesion through single citizenship a more difficult and probably more time-consuming procedure.

We must also acknowledge that the Arcadian federation implemented efficiently single citizenship in an environment where some important aspects such as immigration from other city-states were not intense. By contrast, the EU has to undertake a series of well calculated policies in order to tackle the extensive phenomenon of undocumented immigrants (also known as illegal or unauthorized immigration) mostly observed on its south and southeast territories. In order to effectively implement pan-European single citizenship there must be an efficient management of an EU migration policy. If there is mismanagement, it may mean that both EU citizens and unauthorized immigrants will easily move on from member state to member state and thus any mechanism of supervision of this process will be deregulated for both local member states and EU authorities. It may also increase the level of delinquent behavior within the EU. Thus, single citizenship will not flourish unless an efficient management of immigration will takes place (Note 11).

In addition, a more coherent CFSP is required. To achieve this, more steps on the political level must be undertaken by the EU policymakers. But steps should be taken towards homogeneity regarding military means. Purchasing common weaponry and surveillance systems will offer a privilege in favor of the EU military industry integration: achieving economies of scale. Thus common military means and foreign policy practices will be to the benefit of a more coherent CFSP. Finally, as a general comment, it might be said that in order to improve democracy worldwide, these proposals must also be practiced by other democracies as well. For example, Australia and India must also institute initiatives or referendums or, direct democracy must be further expanded in the other German Lander or the rest of the states of the USA, etc.

We hope that our paper helps the international discussion of promoting democracy and economic cohesion through economic performance as the two basic interactive tools of prosperity for our modern societies (Note 12).

\section{Acknowledgements}

The authors wish to thank the editor and the reviewers for their helpful comments which led to the significant improvement of this work

\section{References}

Ager, S. (1996). Interstate relations in the Greek world 337-90 BC. Berkeley, University of California Press, Los Angeles and London. 
Badian, E. (1952). The Treaty Between Rome and the Achaean League. The Journal of Roman Studies, 42(1/2). 76-80. http://dx.doi.org/10.2307/297516

Cartledge, P. (1987). Agesilaos and the crisis of Sparta. London: Gerald Duckworth and Company.

Davis, S. R. (1978). The federal principle: A journey through time in quest of meaning. Los Angeles and London: University of California Press.

de Laix, R. A. (1973). The Silver Coinage of the Aetolian League. Californian Studies in Classical Antiquity, 6, 47-75. http://dx.doi.org/10.2307/25010647

Diodorus Siculus “Historical Library” (Diod. Hist.).

Eckstein, A. M. (2006). Mediterranean anarchy, interstate war, and the rise of Rome. Berkeley CA: University of California Press.

Economou, E. M. L., \& Kyriazis, N. (2013). The Emergence and the Development of the Federations: The Achaean Federation, the United Provinces and the EU. Munich Personal RePEc Archive, MPRA Paper No. 47349.

Economou, E. M. L., Kyriazis, N., \& Metaxas, T. (2014). The Institutional and Economic Foundations of Regional Proto-federations. Economics of Governance. http://dx.doi.org/10.1007/s10101-014-0155-4

Fine, J. V. A. (1940). The Background of the Social War. The American Journal of Philology, 61(2), 129-165. http://dx.doi.org/10.2307/290732

Fine, J. V. A. (1983). The ancient Greeks: A critical history. Harvard: Harvard University Press.

Freeman, E. A. (1893, repr. 2013). History of federal government in Greece and Italy. General Books.

Gabrielsen, V. (1994). Financing the Athenian fleet: Public taxation and social relations. Baltimore: John Hopkins University Press.

Georgiou, M. N., Kyriazis, N., \& Economou, E. M. L. (2015). Political Stability and Democratic Governance. A Panel Data Analysis. Munich Personal RePEc Archive, MPRA Paper No. 62978.

Hansen, M. H. (1999). The Athenian democracy in the age of Demosthenes. Bristol Classical Press: London.

Hartley, K. (2003). The Future of European Defence Policy: An Economic Perspective. Defence and Peace Economics, 14(2), 107-115. http://dx.doi.org/10.1080/10242690302921

Hartley K. (2007). The arms industry, procurement and industrial policies. In K. Hartley \& T. Sandler (Eds.), Handbook of Defense Economics (pp. 1140-1176). North Holland, Amsterdam, 2007. 
Kaufmann, B., \& Waters M. D. (2004). Direct democracy in Europe: A comprehensive reference guide to the initiative and referendum process. Durham, North Carolina, Carolina Academic Press.

Kaufmann, B., Bóchi, R., \& Braun, N. (2010). Guidebook to direct democracy in Switzerland and beyond. Marburg: The IRI Initiative \& Referendum Institute Europe.

Kyriazis, N. (2009). Financing the Athenian state: Public choice in the Age of Demosthenes. European Journal of Law and Economics, 27(2), 109-127. http://dx.doi.org/10.1007/s10657-008-9081-7

Larsen, J. A. O. (1971). The Rights of Cities Within the Achaean Confederacy. Classical Philology, 66, 81-86. http://dx.doi.org/10.1086/365719

Larsen, J. A. O. (1972). A Recent Interpretation of the Achaean Assemblies. Classical Philology, 67, 178-185. http://dx.doi.org/10.1086/365864

Lewis D. M. (1997). Mainland Greece 479-451 B.C. In: D. M Lewis \& J. Boardman (Eds.), The Cambridge Ancient History, Vol. 5. (pp. 96-120). Cambridge: Cambridge University Press.

Lyttkens, C. H. (1994). A Predatory Democracy: An Essay on Taxation in Classical Athens. Explorations in Economic History, 31, 62-90. http://dx.doi.org/10.1006/exeh.1994.1003

Mackil, E. (2013). Creating a common polity. Religion, economy, and politics in the making of the Greek Koinon. Berkeley, Los Angeles and London: University of California Press. http://dx.doi.org/10.1525/california/9780520272507.001.0001

Metaxas, T., \& Economou, E. M. L. (2012). Security Policy in the European Union and the United States through the Issue of their Defence Expenditures. Journal of Global Analysis, 3, 58-81.

Mitsos, M. T. (1947). Thermika and Panaitolika. Hesperia: The Journal of the American School of Classical Studies at Athens, 16, 256-261. http://dx.doi.org/10.2307/146971

Mosse, C. (1969, repr. 2008). Les institutions grecques à l'époque classique. Paris: Armand Colin.

Pausanias "Hellados Periegiseis" (Paus. Hell. Per.).

Roy, S. (2000). Problems of democracy in the Arcadian Confederacy, in: R. Brock \& S. Hodkinson (Eds.), Alternatives to Athens: Varieties of Political Organization and Community in Ancient Greece (pp. 308-326). Oxford: Oxford University Press.

Roy, S. (2005). Megalopolis. In S. Hornblower \& A. Spawforth (Eds.), The Oxford Classical Dictionary (3 rev. ed.) Oxford: Oxford University Press.

Sakellariou, M. B. (1972). The decline of the hegemonic cities: Mainland Greece and the Aegean, since 404 to 355 BCE, History of the Greek Nation, Classical Hellenism $\left(\Gamma_{1}\right)$, (pp. 414-426). Athens: Ekdotiki Athinon Publications (in Greek). 
Scholten, J. B. (2000). The Politics of plunder: Aitolians and their Koinon in the Early Hellenistic era, 279-217 BCE. Berkeley and Los Angeles: University of California Press.

Schwahn, W. (1931b). Das Burgerrecht der Sympolitischen Bundessaaken beiden Griechen, Hermes, 66, 97-118.

Trampedach, K. (1994). Platon, die Akademie und die zeitgenössische politik. Stuttgard: Franz Steiner Verlag.

Tsiolis, V. (1995). El Thersilion de Megalopolis: Functiones y chronologia, Gerion, 13, 47-68.

Weingast, B. R. (1997). The Political Foundations of Democracy and the Rule of Law. The American Political Science Review, 91(2), 254-263. http://dx.doi.org/10.2307/2952354

Xenophon "Hellenica", (Xen. Hell.).

\section{Notes}

Note 1: An initiative is an institutional procedure undertaken by a democratic environment. An initiative is related to the power or the ability of a citizen or a group of citizens to propose a legal act, which may lead to a national referendum. This proposal may have to do with a variety of issues such as legislation, environmental policies, transportation, health care, etc. In the EU, citizens can collect signatures in order to ask the European Commission to make a legislative proposal based on their own proposal. A number of at least 1 million signatures is required to be collected from at least 7 out of the $28 \mathrm{EU}$ member states. These signatures must be certified by the legal authorities in each EU state. The European Commission then is obliged to examine in three months the initiative and decide how to act on it. However, initiatives in the EU still don't have a binding character. See http://ec.europa.eu/citizens-initiative/public/welcome?lg=en http://www.europarl.europa.eu/atyourservice/en/20150201PVL00039/Citizen's-initiative

Note 2: For example, taking into account the case of Greece, after the Greek economic crisis manifested itself in 2010, Greek policymakers undertook harsh economic measures such as tax on land property which is still in force, the so called "ENFIA" tax. All these measures have caused social outrage because they were not introduced under a consent building strategy, as it would have happened in the Greek democratic federations, where, according to Mackil (2013), direct democratic procedures functioned as a "safety belt" concerning the introduction of any new state policy measures. Thus, excess taxation measures that have been undertaken in the modern Greek economy, without legitimization in the eyes of its citizens, have resulted in the gradual rise of extremist parties and the erosion of the prestige of the EU. See http://www.theguardian.com/world/2012/nov/07/greece-austerity-protests-violence.

Note 3: We owe these comments to both referees.

Note 4: It seems to us that a modern historical paradigm resembles somehow case we describe here. This has to do with the post-WWII antagonism between France and Germany as to the exact status of the sovereignty of the industrial complex of Ruhr, which had plenty of coal and was still the main source of energy till the early 60 's. In order to solve the 
problem and the rising tension between France and Germany, the Europeans, inspired by prominent visionaries such as Monnet, Schumann, Spinelly and Adenauer, decided to take this a step further and to create a pan-European authority, responsible for managing European coal as a whole, the so-called European Coal and Steel Community (ECSC). This incident resembles our two cases: In order to face the threat of further tensions, Tegea and Mantineia decided to create a federal structure with a capital, recognized by both city-states, and the rest of the Arcadian city-states, as a means of solving the problems between them in a more versatile and productive way.

Note 5: http://en.wikipedia.org/wiki/Referendums_in_New_Zealand http://pirateparty.org.au/wiki/Policies/Constitutional_Reform, http://people2power.info/input/ignoring-democracy-new-zealand-style

Note 6: Seignorage is the difference between the face value of a coin and its production cost, for example, the value of silver, labour, capital costs, etc. Seignorage accrues to the issuing authority, in our case, the federation for federal coins and the city-states for city-coins.

Note 7: For this issue, see Fine (1940, 1983) and Eckstein (2006).

Note 8: http://europa.eu/newsroom/highlights/special-coverage/eu_sanctions/index_en.htm

Note 9: There is a great possibility that modern Greece may abandon the euro and the Eurozone. Due to an inefficient way of managing its macroeconomic data, Greece now faces a huge public debt, which is analogous to $180 \%$ of GDP in nominal terms. Many scholars such as Joseph Stiglitz argue that Greece will not manage to recover from this crisis and efficiently repay its debt if a major reconfiguration of its debt does not take place at the end. http://www.marketwatch.com/story/stiglitz-says-greece-didnt-fail-austerity-failed-2015-02-0. 3. The EU aided Greece with two financial packages, called Memorandums in order to repay its debts. However, these packages were accompanied by harsh austerity measures, which had the opposite result. Since 2010 Greece's GDP declined about 30\% and the unemployment rate rose as high as $30 \%$ ! We think that if Greece finally abandons the Eurozone, the so-called "Grexit" as it is commonly known, this will strongly reduce the prestige of the EU and the Eurozone with regard to the rest of the non-EU European states which still seek future membership in the EU.

\section{Note 10:}

http://www.freedomhouse.org/article/freedom-world-2013-middle-east-gains-provoke-intensi fied-repression\#.U24E-3Z7TxU, retrieved, June, 04, 2015.

Note 11: The above ideas are based on the comments we have received from both referees.

Note 12: For a detailed discussion about how democratic regimes are interconnected with political stability and economic performance see Georgiou, Kyriazis and Economou (2015) who also offer additional references.

\section{Copyright Disclaimer}

Copyright reserved by the author(s).

This article is an open-access article distributed under the terms and conditions of the Creative Commons Attribution license (http://creativecommons.org/licenses/by/3.0/). 